\title{
Regerach Aвтісl: Application of a decision support system of farm implements and machinery for selected crops of Kerala
}

\section{A. PARVATHY, D. NANJAPPA AND M.T. LAKSHMINARAYAN}

Article Chronicle : Received : 18.07.2017;

Revised :

29.08.2017;

Accepted :

15.09.2017

Key Words :

Decision support

system, Farm

mechanization

Author for correspondence :

\section{A. PARVATHY}

Department of

Agricultural Extension

Education, University

of Agricultural Sciences, DHARWAD (KARNATAKA) INDIA

See end of the article for authors' affiliations
SUMMARY : The study was conducted during 2014 to find out the utility of the decision support system (DSS) developed in farm mechanization in selected crops for extension personnel and farmers of Kerala state. The application of the decision support system "farm mechanization" obtained a positive feedback from the end users. The most important utility of the system for extension personnel was as a ready reference material to refresh and enhance the knowledge on the subject and also as a training tool to enhance the learner participation. These two utilities were perceived by 90 per cent of the respondents. The most important use of the decision support system "Karshika yanthravalkaranam" for farmers was a tool to satisfy information need of farmers to take a decision on farm implement or machinery required for their crops as perceived by 83 per cent of the respondents.

How to cite this article : Parvathy, A., Nanjappa, D. and Lakshminarayan, M.T. (2017). Application of a decision support system of farm implements and machinery for selected crops of Kerala. Agric. Update, 12(4): 574-577; DOI : 10.15740/HAS/AU/12.4/574-577. 